\title{
Islamic Period Settlement in the Tell Leilan Region (Northern Jazira): The Material Evidence from the 1995 Survey
}

\section{Valentina Vezzoli}

This paper provides an initial evaluation of the settlement dynamics in the area around Tell Leilan (Northern Jazira) during the Islamic period based on the study of the ceramic material collected during the 1995 survey campaign. It concentrates on the description of ceramic groups and diagnostics, and is thus able to give a reliable dating for the Islamic period occupation in the region and allows us to trace an outline of settlement development in this rural landscape. The resulting patterns are discussed in the wider context of archaeological investigations in Northern Mesopotamia and Syria generally, and compared with data derived from textual sources which have generally provided a partial and incomplete account.

Keywords: Islamic pottery, Northern Jazira, Tell Leilan Region Project

\section{Introduction}

The present contribution is a part of a research project which is being carried out by a team from the Cà Foscari University of Venice, under the responsibility of Professor Elena Rova, in cooperation with the Yale University Tell Leilan project, directed by Professor H. Weiss. It is based on the study of the pottery assemblage collected during the 1995 survey at Tell Leilan, now stored at the Department of Sciences of Antiquity and of Near East (Cà Foscari University of Venice), with a particular focus on the material of the Islamic period. The analysis of this assemblage allows us to make some preliminary remarks concerning the nature of human settlement in Northern Jazira between the Early Islamic (7th-8th centuries AD) and the end of Ottoman period (19th century AD). The article is based upon the writer's MA thesis, L'insediamento di epoca islamica nell'area di Tell Leilan (Jazira settentrionale): studio del materiale ceramico (Vezzoli 2003-04).

\section{The Tell Leilan Region}

The site of Tell Leilan is located in North-east Syria, in the northern half of the Khabur plain, an

Valentina Vezzoli, Cà Foscari University of Venice, Department of Eurasian Studies, Cà Cappello San Polo 2035, Venezia, Italy; e-mail: vvezzoli@ hotmail.com undulating extent of fertile soils. In the north, the plain is essentially at the piedmont of the Tur 'Abdin where the local wadi systems have their origin. In the south the plain terminates in the marshy depression of the Wadi Radd, which is also fed by streams originating from the Jebel Sinjar in present-day Iraq. The main body of the plain is composed primarily of reddish-brown overbank flood deposits and sands. Geomorphological work undertaken as part of the Tell Leilan project has included both a soil survey and exploration of regional hydrology in order to characterize land-use potential (Besonen and Cremaschi 2002). It was possible to establish a definite north-south landscape division based upon differences in hydrology. Precipitation is highest in the north (c. $440 \mathrm{~mm}$ at present) due to the orographic effect of the hills of the Tur 'Abdin, but rapidly decreases to $220 \mathrm{~mm}$ in the Wadi Radd basin (Courty and Weiss 1997, 112). In the north, soils are calcic (red and brown Mediterranean soils), while those to the south are gypsic.

The geology of Northern Mesopotamia and microenvironmental differences in hydrology, soil type and precipitation, influence the fertility of this area (Ristvet 2005, 45-46). In antiquity and in the middle ages the region was a centre for extensive wheat and barley cultivation and it currently produces one quarter of Syria's annual cereal crop, without the aid of irrigation. 


\section{Archaeological Data and Written Sources: Two Distinct Voices}

Textual and archaeological sources provide different, at times contrasting, information concerning the history of human settlement in this part of the Jazira during the Islamic period. The documentary sources generally present a partial description of the area. Arab authors of the Islamic period have mainly commented upon the most important sites of North Syria, such as al-Raqqa or Tell Sheikh Hasan, which were once interregional centres (Bartl 1993-94, 30), or regional centres like Ra's al-'Ayn and Qarqisiya. However, they provide little information on small centres and villages; the area surveyed around Tell Leilan is a case in point. The kind of information we can extract from texts refers mainly to important historical events, or to geographical descriptions. While in the latter case they provide a quite useful overview of cultivation practices and the landscape of the Jazira, they do not allow us to tackle the problematic issue of the dynamics of rural settlement at different points within the Islamic period (e.g. the impact upon rural communities of changes in rulers, the relationships between villages and central authorities, even the size and the location of smaller settlements). At times documentary sources provide a distorted vision of reality, because they often represent the concerns of dominant political groups. For these reasons it is necessary to integrate the evidence of documentary sources with archaeological data that can provide evidence relating to Islamic period settlement.

\section{The Historical and Geographical Context Based on Textual Evidence}

It is necessary at this point to offer brief, critical account of the documentary evidence examined in the course of this project. Two different types of written sources can be identified:

a. primary Arabic-language sources from medieval authors;

b. the secondary sources from Europeans travellers who visited Syria at the beginning of the 19th century and who attempted to reconstruct the historical topography of this region.

The Khabur Valley formed an important connection between west Syria and Southern Mesopotamia. In the Islamic period the area was traversed by the Euphrates trade route (Fig. 1) which connected Aleppo to Mosul across the North Mesopotamian plateau (Ra's al-'Ayn). Yaqut and other medieval geographers mention centres located along the
Abbasid road (Fiey 1964, 107-17) nameley: Ra's al-'Ayn, Balad, Ba'aynatha, Barqa'id, Adhrama and Bajadda (Yaqut 1977; Al-Muqaddasi 1967; Ibn Hawqal 1964). Some of these centres have now been identified with modern villages or towns. At the beginning of the 20th century Adhrama was tentatively identified with Tell Leilan. This however is unlikely, as little evidence of Islamic period occupation has been found at the site. However, working on the distances between the different stations, it is nevertheless possible that Adhrama was located in the region around Leilan. Except for those centres located along the Abbasid road, settlements in the Tell Leilan region, the Khabur Valley in general, are not usually mentioned by the Islamic sources, presumably because of the lack of major centres in the area.

The Arabic-language historical and geographical literature - for example, Ibn Khurradadhbih's Kitab al-masalik wa al-mamalik (1967); al-Hamdani's Sifat Jazirat al-'Arab (1968), Ibn Hawqal and the Kitab ahsan al-taqasim fi ma'rifat al-aqalim of al-Muqaddasi (1967), the Tuhfat al-nuzzar fi ghara'ib al-amsar by Ibn Battuta (1957) and Yaqut's Mu'jam al-buldan (1977) - provides information about the administrative structure of the caliphate, agricultural production and the main centres of the Jazira. However, its value for the reconstruction of the historical and geographical context of this peripheral area is limited. Medieval geographers do, however, provide a general description of the rural landscape of North Jazira. Ibn Shaddad (1964, 44), writing in the 13th century $\mathrm{AD}$, provides a list of regional products such as wheat (qumh), rice (aruzz), sesame (simsim), grapes (a'nab), cotton (qutn) and sugar cane (qasb as-sukkar). According to such sources, North Mesopotamia was a rich agricultural land, but a difficult political situation and the presence of tribal groups rendered its role somewhat peripheral.

The period between the 10th and 11th centuries AD was marked by political instability caused by stronger particularistic tendencies in the area of North Syrian/ North Mesopotamian. This fact at least partially explains the apparent decrease in settlement activity. During the Ayyubid period (12th-late 13th centuries AD) and the subsequent rule of the Mamluks, from late 13th century $\mathrm{AD}$ to the second half of the 14th century $\mathrm{AD}$, the area witnessed a period of political stability and economic development. While medieval authors suggest that the Jazira was completely destroyed by a Mongol invasion in $1260 \mathrm{AD}$, the archaeological evidence does not appear to confirm this situation (see below). 


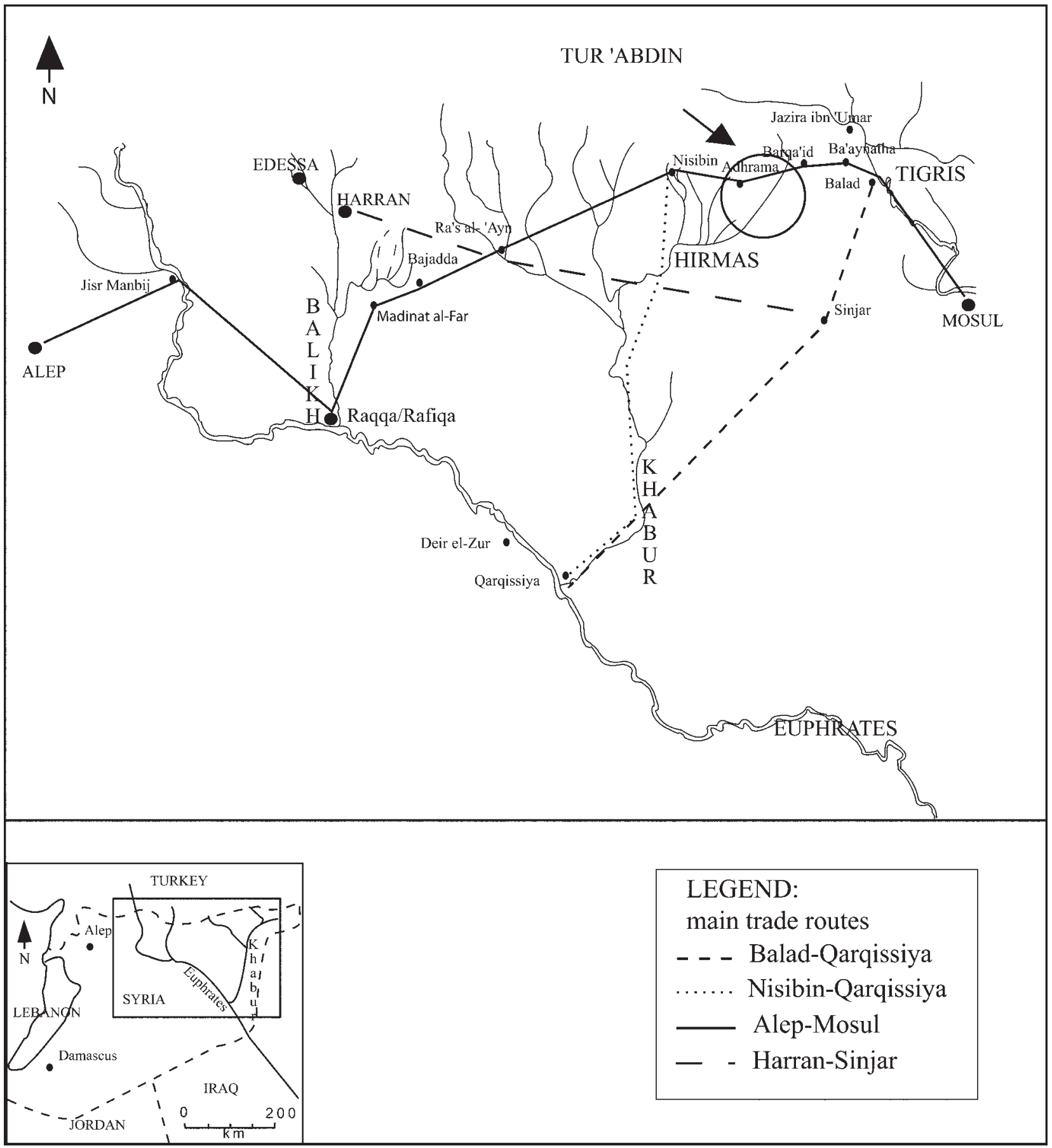

Figure 1 The area of the 1995 Survey at Tell Leilan and main trade routes of Northern Mesopotamia

The situation worsened after the 14th century AD. By the fall of the Mamluk dynasty, the region was overrun by tribal groups, who threatened the security of commercial traffic and agriculture. The tension caused by the rival tribal groups was one reason for a marked reduction in sedentary communities, a point confirmed by both written sources and archaeological evidence. This same is true for the entire Ottoman period, as Ottoman rulers were unable to reach a political agreement with the local tribes. When the first European travellers visited this region, in the 18th century $\mathrm{AD}$, it was recorded as a steppe or deserted area intermittently occupied by Kurds, Arabs and Yezidis. Although largely uninhabited in the 19th century, North Jazira is today populated by a sprinkling of villages, the inhabitants of which can claim either Arabic and/or Kurdish as their mother tongue, a development that is due in part to the agrarian reforms of the earlier 20th century. 


\section{The Tell Leilan Region Survey}

The Tell Leilan Region Survey Project aims to investigate the history of human occupation in this part of North Mesopotamia over the last 10,000 years by collecting new data about environmental change, the socio-political situation and settlement dynamics.

The area surveyed includes a transect of some $30 \mathrm{~km}$ in width running southwards from the Turkish border to the Wadi Radd and corresponds to a total area of around $1650 \mathrm{sq} \mathrm{km}$ (Ristvet 2005, 36). The identification of archaeological sites by using the data collected during previous investigations (e.g. Meijer 1986) and surveys carried out in the neighbouring areas (Lyonnet 1992) was developed through the use of satellite maps and by pedestrian survey in the field.

A systematic, total-coverage survey has been developed over several seasons of fieldwork (1984, 1987, 1995 and 1997), with a total of 324 sites identified, which span the Aceramic Neolithic to the end of the Ottoman period. The field team collected diagnostic ceramics, kiln-wasters, lithic material and other objects from all periods. A detailed description of the survey methodology has been provided by Ristvet (2005, 35-36), associate director of excavations at Tell Leilan, and so this information is not repeated in extenso here.

The first survey campaign of 1984 covered an area of some $706 \mathrm{sq} \mathrm{km}$ with 90 sites identified. During the second season (1987), Stein and Wattenmaker resurveyed the 1984 area with a focus upon the organization of the countryside in the 3rd millennium BC (Stein and Wattenmaker 2003). During the 1995 and 1997 seasons new sites in the south of Tell Leilan were investigated and sites identified in 1984 were revisited. The new sites were divided into quadrants and material from each quadrant collected separately; some selected sites were also investigated using a system of linear transects division, starting from the top of the mound till the feet. The archaeological investigation had employed LANDSAT, SPOT and CORONA satellite imagery, and used GPS to fixed site coordinates, and topographic maps ranging from $1: 100,000$ to $1: 10,000$. Preliminary data about the various bodies of preliminary information on the Tell Leilan Region Survey have been published (Weiss 1986; Stein and Wattenmaker 1990, 2003; Weiss 2003; Weiss et al. 2002; Risvet 2002, 2005, Ristvet and Weiss 2005).

\section{The 1995 Survey}

\section{The Finds of the Islamic Period}

The sherds material from the 1995 survey at Tell Leilan is stored at the Department of Sciences of
Antiquity and Near East, Cà Foscari, University of Venice and has been studied in the course of various MA theses. In the case of material from the Islamic period, the 1995 survey at Tell Leilan has produced a good sequence of artefacts for the different chronological phases of occupation, and it was decided to focus upon three main categories: Glazed Pottery, Unglazed Pottery and Other Objects, as their potential for dating is rather different.

Special attention is devoted to the Glazed Pottery, which has been treated more extensively in the archaeological literature than other groups of material, and the chronological developments of which are better understood because of stratified evidence from the excavation of multi-period sites. Glazed pottery, however, represents a small proportion (less than $25 \%$ ) of the total ceramic assemblage from the survey, with no more than 60 fragments having been identified.

In the case of the Unglazed Pottery, which represents around $75 \%$ of the ceramic assemblage (198 fragments), except for some special categories of material, the material collected in the 1995 survey provides only a very general chronological indicator, because it shows distinctive local features, which restrict our ability to identify parallels with material excavated in other areas. However, this rather small sample is sufficient to suggest a preliminary periodization of the Islamic occupation in the region.

\section{Chronology of the Islamic Period Settlement}

Among the regions of Syria, the area between the Euphrates and the Khabur Valley was rather neglected by archaeological research (Bartl 1993$94,29)$ until the beginning of the 1980s, when there was a surge in archaeological work. This new interest was, however, primarily focused on the prehistoric and early historic periods. The two first excavation projects focusing on the Islamic period were at Madinat al-Far (Saliby 1983, 69-88; Haase 1991, 206-25; Haase 1996, 165-71; Haase 2001, 720 ) in the north of the Balikh Valley and al-Raqqa/ al-Rafiqa (Meinecke and Heusch 1985, 85-105; Meinecke 1991, 17-32; Meinecke 1995, 424-28). The data obtained from both of these excavations, as well as from other archaeological work, both excavations and surveys in the Jazira, were included in this study of the Islamic period occupation in the Leilan area.

Using available historical and archaeological sources, it was possible to establish an internal periodization of the Islamic settlement, albeit with some deficiencies. For example, no material evidence 
has been identified which can be securely dated to the first two centuries of the Islamic period (7th and 8th centuries AD). It is possible, of course, that this reflects our limited ability to recognize and date the common wares of the Early Islamic period. There are a few fragments which may date to either the Late Roman/Sasanian or the Early Islamic periods, and which will be studied further in the due course, in collaboration with specialists working on the Hellenistic through Sasanian material (De Aloe 2002-03).

The chronological limits for the Islamic period occupation are presently fixed between the late 8th century $\mathrm{AD}$ and the late Ottoman Period (19th century-beginning of the 20th century AD). Six phases were identified in the course of this study thanks to the pottery evidence. This chronological division is based on the most recent results in archaeological literature for this area.

1. Early Islamic Period (late 8 th-9th centuries AD)

2. Abbasid Period (10th-11th centuries AD)

3. Ayyubid Period (12th-13th centuries AD)

4. Mamluk Period (late 13th-14th century AD)

5. 'Late Islamic' Period (15th-16th centuries AD)

6. Ottoman Period (17th-beginning of 20th century $\mathrm{AD})$

The first four phases can be clearly identified in the archaeological record, although with rather different intensities. A significant drop in the number of occupied sites characterized the last two phases during which the area appears to have been heavily depopulated (Fig. 2).

\section{The Islamic Period Sites of the 1995 Tell Leilan Survey (Table 1)}

The material evidence collected during the 1995 survey at Tell Leilan provides the following, preliminary data regarding Islamic period settlement patterns in the region surrounding Tell Leilan, and which have to be integrated with that from the 1997 survey in the same region, now stored in the excavation house at Qahtaniye. A total of 104 sites were investigated, 47 of which produced ceramics indicating some kind of occupation during the Islamic period. Only four sites yielded more than 20 fragments of Islamic pottery: Gir Sikha (27), Shair (36), Sharmukh (26) and Tell Haid (24). Ten sites produced 5-10 fragments and 15 sites $2-4$ fragments (Tell Leilan is included in the latter group). Thirteen sites produced only one fragment. However, even the sites with the largest sherd collections measure less than 4 ha in extent, with the exception of Tell Haid,

\section{the Islamic period settlement}

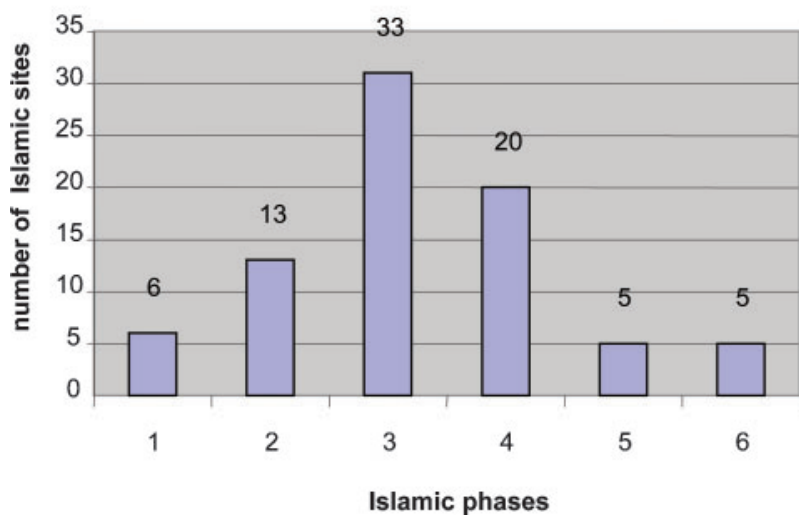

Figure 2 Graph showing the number of sites occupied during the six identified phases of the Islamic period

which extends to around 20 ha, although this includes significant components of earlier occupation. None of these sites can therefore be considered as representing more than a large village. The other sites show evidence for only limited occupation during the Islamic period.

On the basis of the archaeological evidence, it is possible to identify three main phases in the development of Islamic period settlement around Tell Leilan. Nineteen sites can be attributed to a period dating between the late 8 th and the 11 th centuries AD. Three of these produced a significant number of sherds, and may represent large villages: Gir Sikha (site 116), Shair (site 74) and Sharmukh (site 59). In these centuries settlement appears to have developed most strongly in the northern part of the survey area (Fig. 3).

During the 12 th and the 13 th centuries $A D$, the number of Islamic period sites in the area increases, to reach a total of 33 sites (Fig. 4). Four of these can be considered large villages. Three of these are the same 'large villages' as were noted in the previous period, with the addition of Tell Haid (site 90). All of these sites were located north-west of Tell Leilan (site 1), and in general settlement growth occurred mainly in the northern part of the survey area. In the following period (late 13th-14th centuries AD) 20 sites provided evidence for occupation (Fig. 4).

The number of sites shows a significant decrease during the last phase of occupation (15th-19th centuries AD), when far fewer sites are occupied (Fig. 5). The evidence points to Gir Sikha (116), and Shair (74), as having been the main centres but neither shows a significant presence of Late Islamic pottery. However, this period is particularly characterized by the production of unglazed ceramics, and the numbers 
may have been underestimated, as this aspect of the evidence remains poorly understood.

\section{The Pottery Assemblage}

This section presents the groups of Islamic period pottery that were identified among the material collected during the 1995 season. The descriptions contain information about the ceramic body (no petrographic analysis was undertaken), decoration, chronology and recent bibliography.
The ceramics were divided into three main groups: Glazed pottery, Unglazed pottery and Other Objects.

\section{Glazed Pottery}

This represents less than $25 \%$ of the total assemblage. Glazing is associated with wheel-thrown pottery, either with an earthenware body, or with a body that is very rich in silica (so-called Fritware). The following ceramic classes have been identified among the surveyed material:

Table 1 Table showing the periods of occupation present at each site. Six phases of occupation have been identified spanning the period from the 8th-9th centuries to the late 19th century $A D$. In the table $X$ signifies that five or less sherds of Islamic date were recorded, XX signifies that more than five Islamic period sherds were recorded

\begin{tabular}{|c|c|c|c|c|c|c|c|c|}
\hline $\mathbf{N}^{\circ}$ sites & Site & $\mathrm{N}^{\circ}$ Frag. & $\begin{array}{l}\text { Early } \\
\text { Islamic }\end{array}$ & 'Abbasid & Ayyubid & Mamluk & $\begin{array}{l}\text { Late } \\
\text { Islamic }\end{array}$ & Ottoman \\
\hline & & & IX & $X-X I$ & $X I I-X I I I$ & XIV & $X V-X V I$ & \\
\hline 60 & ABU FARA & 14 & $x$ & & $X X$ & & & \\
\hline 164 & AL AMRI SAGHIR & 3 & & & $x$ & $x$ & & \\
\hline 156 & AREMISH & 2 & & & & $x$ & & \\
\hline \multirow[t]{2}{*}{144} & AWENA & 2 & & & $x$ & & & \\
\hline & BALAK & 1 & & & $x$ & & & \\
\hline 137 & BARHAM & 3 & & & & $x$ & & \\
\hline 121 & BARQIYA & 2 & & $x$ & & $x$ & & \\
\hline 181 & BAYAZA SAGHIRA E KABIRA & 4 & & & $x$ & & & \\
\hline 88 & BRAISCH & 6 & & $X$ & $x$ & $x$ & & \\
\hline 143 & BULUDIYA & 1 & & & $x$ & & & \\
\hline 279 & FAWQANI & 1 & & $x$ & & & & \\
\hline 116 & GIR SIKHA & 27 & $x$ & & $X X$ & $X X$ & $x$ & $x$ \\
\hline 151 & GRE PRE & 5 & $x$ & & & $x$ & & \\
\hline 125 & HAMEID & 3 & & & $x$ & & & \\
\hline 122 & $\mathrm{HASHI}$ & 3 & & & & $x$ & $x$ & \\
\hline 76 & JIHAN & 12 & $x$ & $X$ & $X X$ & $x$ & & \\
\hline \multirow[t]{2}{*}{85} & KHAZNA & 5 & & & $x$ & $x$ & & \\
\hline & KH. ABIAD & 3 & & & $x$ & & & \\
\hline 319 & KH. JAHASH & 8 & & & $X X$ & & & \\
\hline 66 & KH. SUFIYE & 1 & & & $x$ & & & \\
\hline 177 & KH. TAYER & 1 & & & $x$ & & & \\
\hline 123 & KHODOR & 7 & & $X$ & $x$ & & & \\
\hline 126 & LAQA & 6 & & & & $X X$ & & \\
\hline 257 & LAZAQA & 5 & & & $x$ & & & $x$ \\
\hline 1 & LEILAN & 2 & & & $x$ & & & \\
\hline 67 & MAGRANAT & 2 & & $X$ & & & & \\
\hline 149 & MALISH & 2 & & & $x$ & & & \\
\hline 155 & MAQBARA & 4 & & & $x$ & $x$ & & \\
\hline 69 & MARJAN EAST & 1 & & & $x$ & & & \\
\hline 134 & MITANYE & 5 & & $x$ & $x$ & $X$ & & \\
\hline 111 & MUGHASEL & 1 & & & $x$ & & & \\
\hline 92 & NASR RM & 2 & & $x$ & & $x$ & & \\
\hline 153 & QATRANIYA & 2 & & & & & & $X$ \\
\hline 217 & QURTABA & 1 & & $x$ & & & & \\
\hline 9 & REHAYA & 5 & & $X$ & & & & $X$ \\
\hline 154 & SAMER & 1 & & & $x$ & & & \\
\hline 74 & SHAIR & 36 & $x$ & $X X$ & $X X$ & $x$ & & $x$ \\
\hline 59 & SHARMUKH & 26 & & $x$ & $X X$ & $x$ & $x$ & \\
\hline 118 & SHIBANYA & 2 & & & $x$ & & & \\
\hline 115 & SIKHA KABIRA & 1 & & & $x$ & & & \\
\hline 135 & TANNURIYE & 1 & & & $x$ & & & \\
\hline 145 & TARTAB & 3 & & & & & $x$ & \\
\hline 180 & TELL GHAZAL & 1 & & & $x$ & & & \\
\hline 90 & TELL HAID & 24 & & & $X X$ & $X X$ & $x$ & \\
\hline 96 & TELL KOUBEIBA & 1 & & & & $X$ & & \\
\hline 106 & TOUEIYEL & 12 & $x$ & & $X X$ & $x$ & & \\
\hline \multirow[t]{2}{*}{280} & UMM ADAM & 7 & & $x$ & $x$ & $x$ & & \\
\hline & & 267 & 6 & 13 & 33 & 20 & 5 & 5 \\
\hline
\end{tabular}




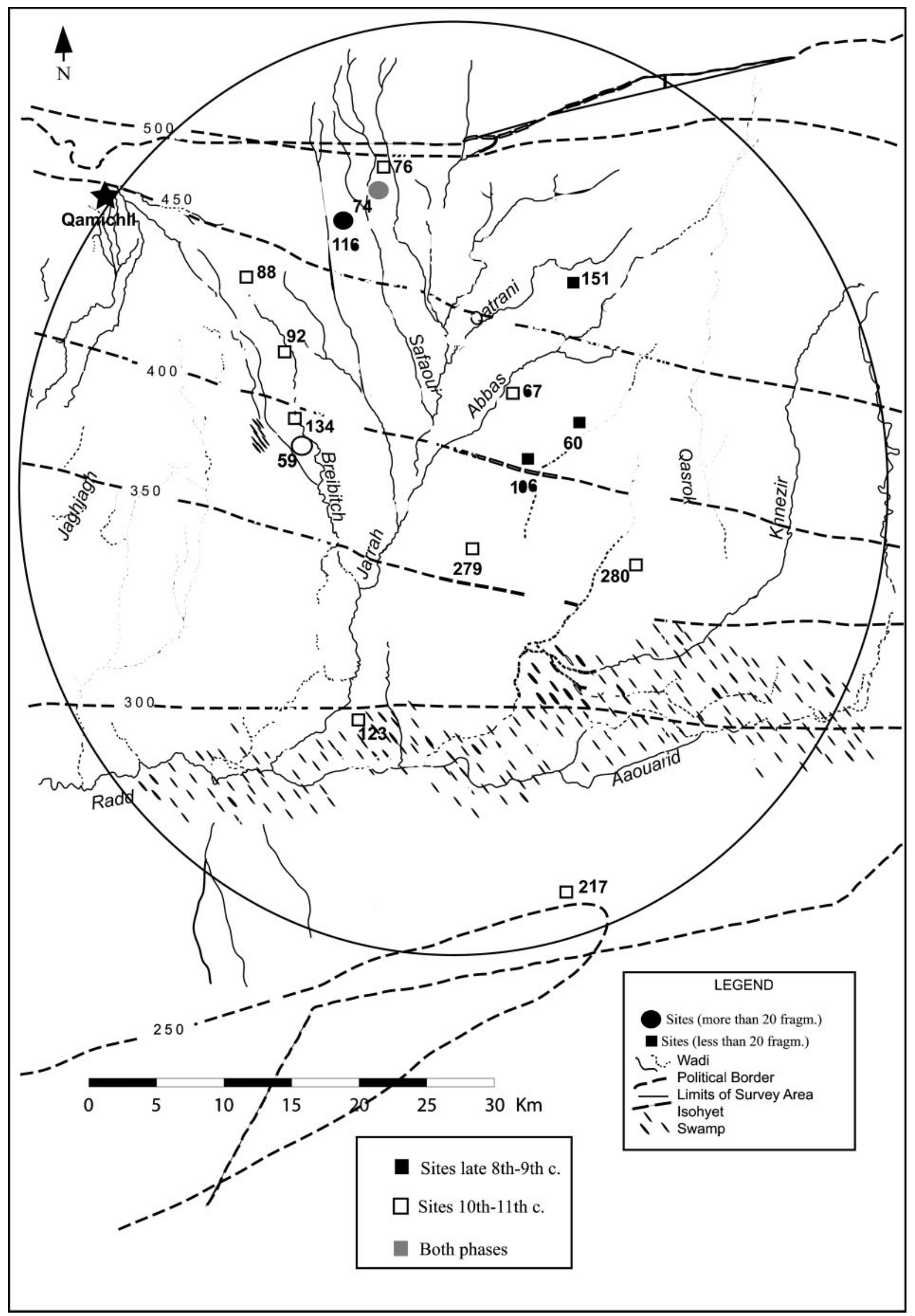

Figure 3 The Islamic-period settlement between the late 8th century and 11th century AD 


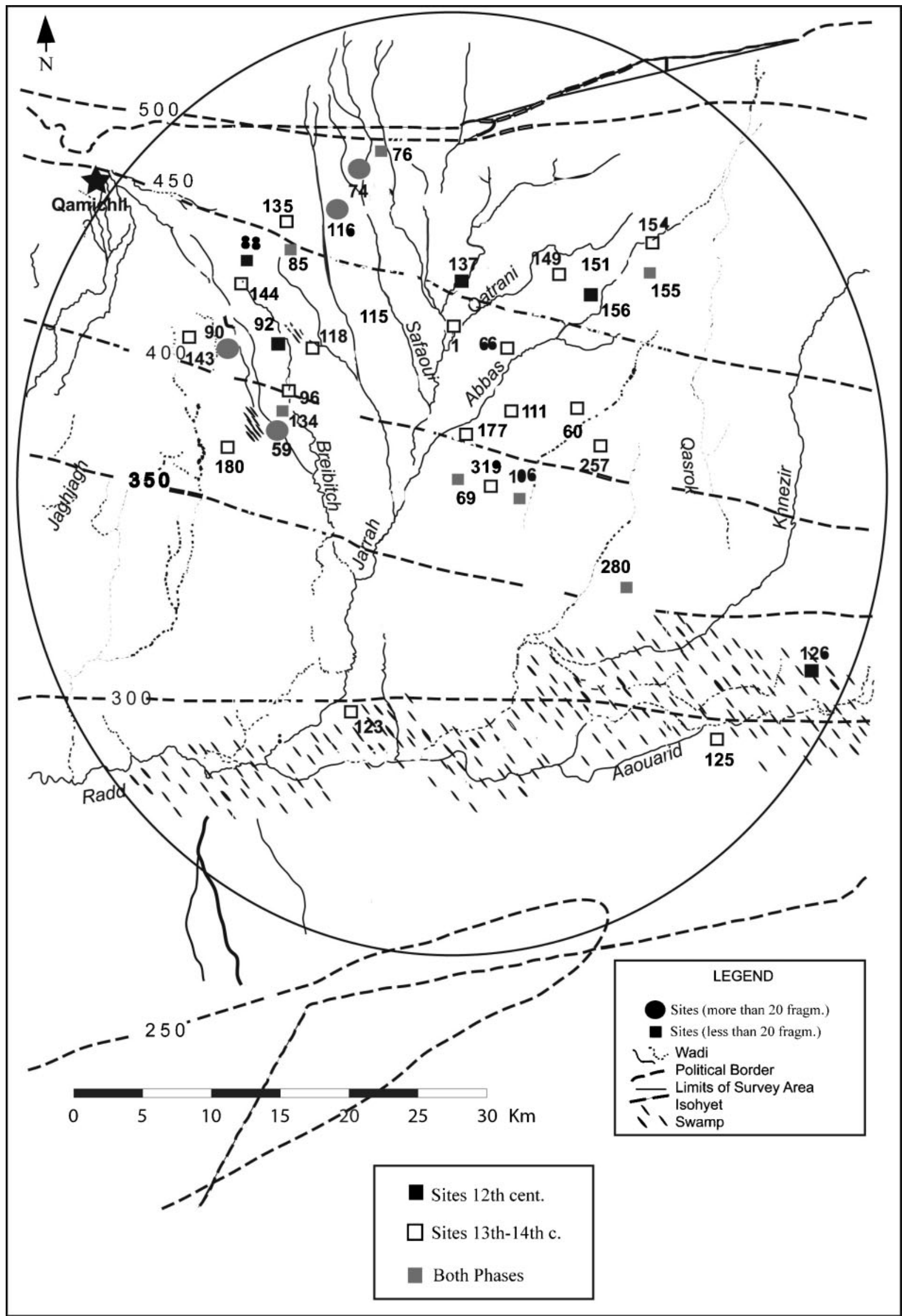

Figure 4 The Islamic-period settlement between the 12th century and 14th century AD 


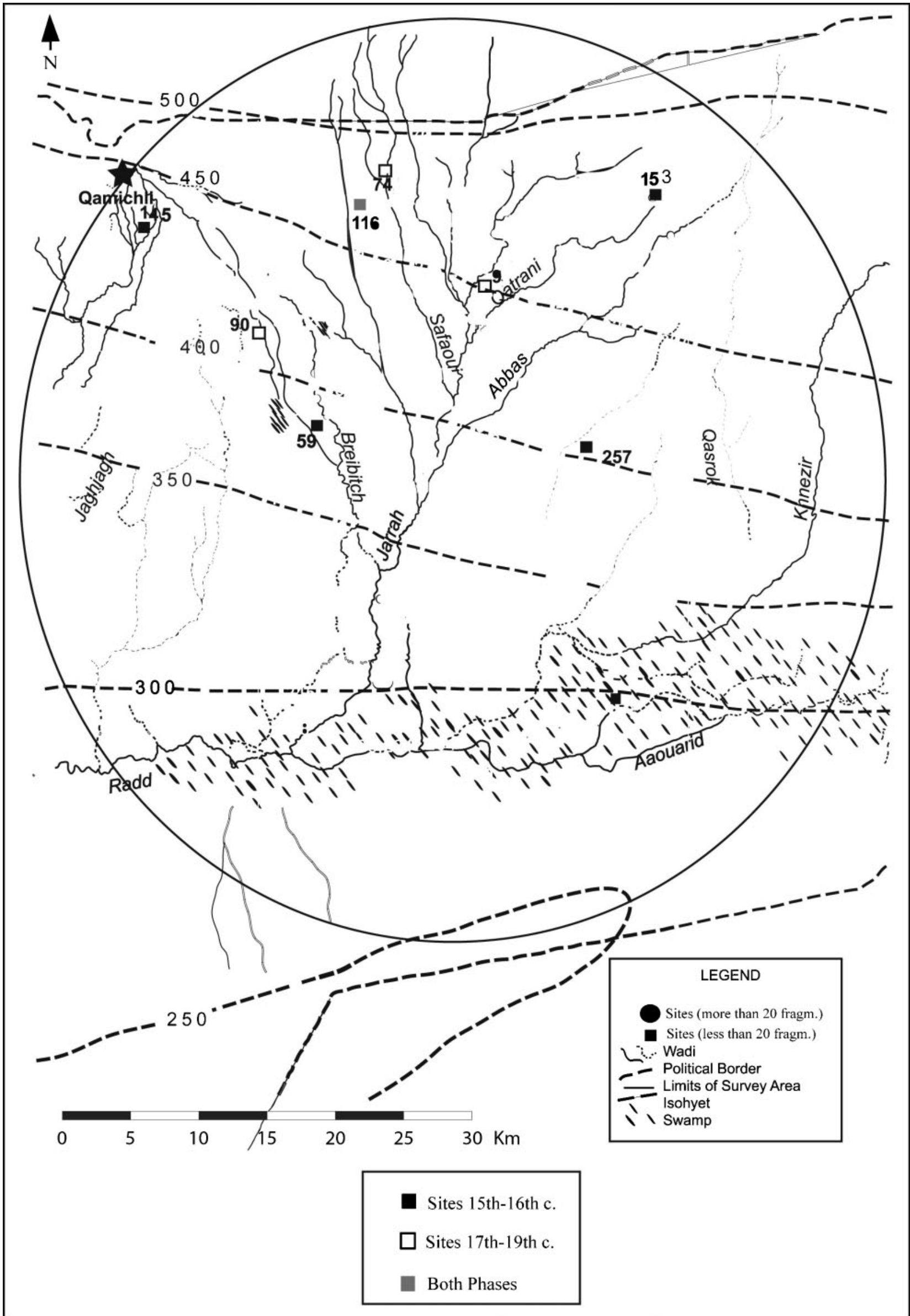

Figure 5 The Islamic-period settlement between the 15th century and late 19th century AD 

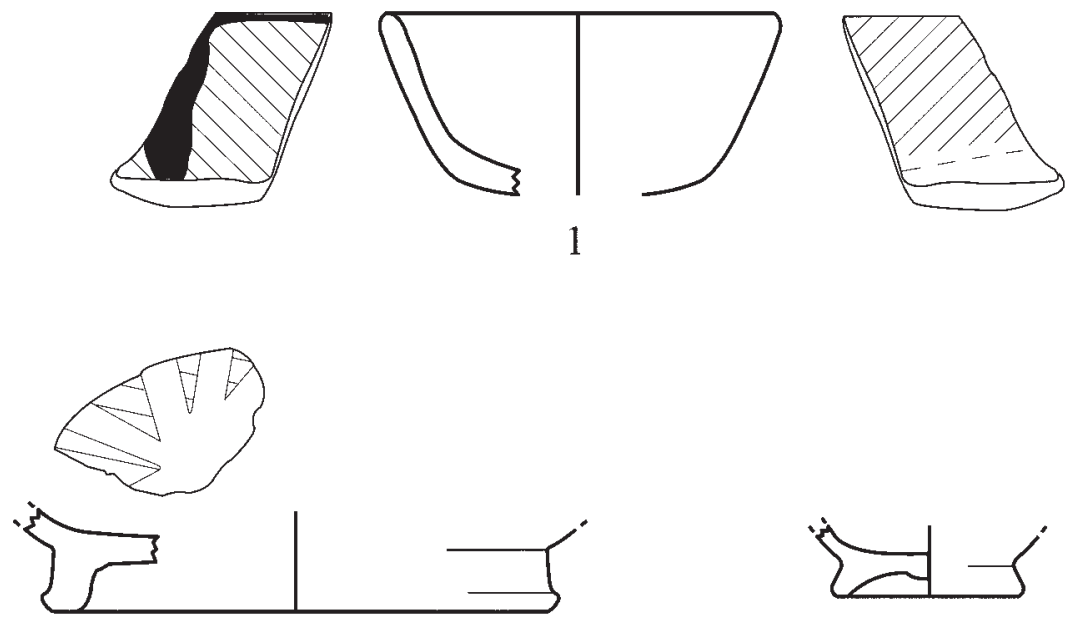

2
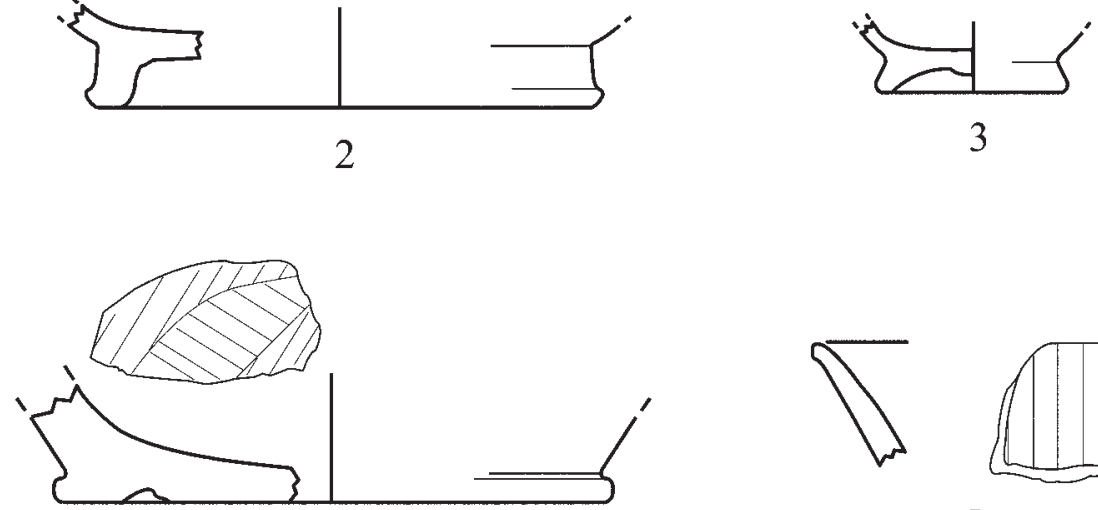

4
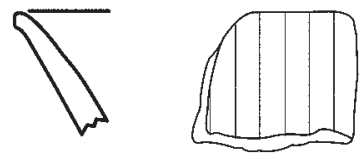

5
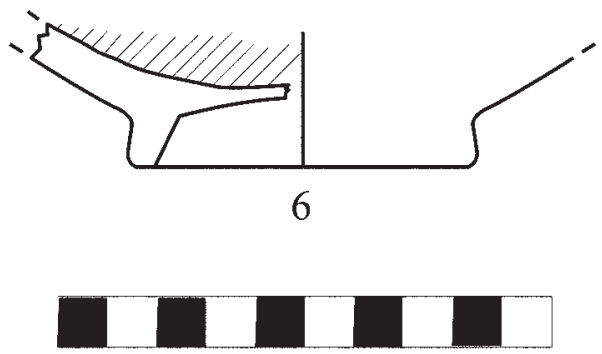

Figure 61 Shair SW 40: Splash Ware. Green and aubergine splashes on the inner surface and yellow splashes on the outer; 2 Shair 49: Fritware 2. Opaque and thick white glaze with lustre decoration; 3 T. Haid 10: Fritware 1. Transparent and colourless glaze on the inner surface; 4 Gir Sikha 34: Yellow and Green Ware; 5 Gir Sikha 1: Turquoise-glazed Ware; 6 Khodor 65: Monochrome green glazed ware

\section{Splash Ware}

This is characterized by a hard, reddish, sandy fabric, and a white or yellowish slip with flecks, daubs and splashes of green, brown and/or violet applied under a thin transparent overglaze (Fig. 6: 1). Attributed to the early Islamic period (second half of 8th centurybeginning of 9 th century AD), it is mostly characterized by open, ring-based bowls or dishes.

\section{References}

Balikh: Bartl 1996, 335, fig. 5: 1-4

Tarso: Ettinghausen and Grabar 1991, 111

'Ana: Northedge et al. 1988, fig. 39: 11c.

Samarra: Sarre 1925; Northedge 1985, 122, fig. 4: 12; Northedge 1996, 229-58.

Tell Abu Sarifa: Adams 1970, 108-10, fig. 11, a, b, g-k, p, q.

\section{Yellow and Green Ware}

The body is usually hard and compact and of pink or orange colour. On the basis of glaze, different groups of Yellow and Green Ware can be distinguished: yellow glazed, green glazed, yellow and green glazed (Fig. 6: 4). This group is associated with table ware and especially bowls. The most common shape is a hemispherical bowl with a rounded rim. Tell Aswad (al-Raqqa) has provided most of the current information regarding this ceramic type. Based on that material it is possible to date Yellow and Green Ware mainly between the 9th and the 10th centuries $\mathrm{AD}$, although it continued to be produced into the 11 th century AD. 


\section{References}

Tell Aswad: Watson 1999, 81-82, pls 94-97. Samarra: Northedge 1996, group IV B, 246. Apamea: Rogers 1984, 262-87, $271 \mathrm{ff}$. Qasr al-Hayr as-Sharqi: Grabar et al. 1978, 114. Balis/Maskana: Golvin and Raymond 1974. Al-Mina: Lane 1938, pl. 19: 1.

\section{Fritware}

This is characterized by an artificial body composed of clay mixed with finely ground silica, usually quartz. The ware can be white, light yellow, greyish or pinkish, depending on firing and on the purity of clay and quartz. Three different groups can be identified, based on the quality of its matrix.

The body of Fritware Type 1 is pure white, compact, fine-grained and hard. It may have a monochrome glaze (turquoise), but it more often appears in the lustre-decorated variety. The main morphological diagnostic feature of Fritware Type 1 is the shape of the base, which is cut in such a way that the bowl rests on a sharp edge, differing from the more common flat base (Fig. 6: 3). Rim shapes are less diagnostic. Fritware Type 1 was first produced in the 11th century AD and was in use until the end of the 12 th century AD.

\section{References}

Damascus: Mc Phillips 2004, 90-134, 224-29, figs 1-20.

Oa'lat Ja'bar: Tonghini 1998, 38-42, figs 42-52.

Tell Minis: Porter and Watson 1987, 175.

Hama: Poulsen 1957, 132-56.

Antioch: Waagé 1948, groups IA5, IB2, IC6, IIA5, IIB2, IIC1, IVD1, XIIC1, XIIC3, XIIC5, XIIC11.

The body of Fritware Type 2 is very rarely white, but it is more often a light yellow or greyish colour, and is porous, fine grained and friable. Fritware Type 2 may also be lustre-decorated (Fig. 6: 2), but the socalled underglaze painted decoration is more characteristic of this ceramic type, and is commonly called 'Raqqa Ware'. It makes its appearance at the beginning of the 12th century $\mathrm{AD}$ and its production continues until the first half of the 13th century AD.

\section{References}

Damascus: Mc Phillips 2004, 90-134, 224-29, figs 1-20. Qa'lat Ja'bar: Tonghini 1998, 46-51, figs 54-56, 57-58, 64-71. Raqqa: Mason 1995, 9-10. Samsat: Redford 1995, 65-66, fig. 10: QQ, fig. 12: CCC. Oasr al-Hayr as-Sharqi: Grabar et al. 1978, 121, 123. Hama: Poulsen 1957, BVII-BVIII, 157-82. Harran: Rice 1952, 45, 47-48, 52, 66-73.

The body of Fritware Type 3 resembles that of Fritware Type 2, being yellowish and rather friable. Examples of this variety of Fritware may have a plain monochrome glaze, carved decoration, or they may be lustre-decorated. It first appeared at the end of the 12th century AD and continued throughout the 13th century AD.

\section{References}

Oa'lat Ja'bar: Tonghini 1998, 51-55, figs 71-75.

St. Mary of Carmel: Pringle 1984, 107-9, fig. 9.

Tell Qaymun: Ben-Tor et al. 1979, 74-76, fig. 5: 3

Oasr al-Hayr as-Sharqi: Grabar et al. 1978, 117.

Hama: Poulsen 1957, groups BXIb-f, BXII; Riis 1957, 28-29.

Fritware Type 1 is covered by a lead glaze, while lead is absent from the glazes of Fritware Types 2 and 3, which are consistently alkaline (Tonghini 1998, 38$55)$.

\section{Turquoise-glazed Ware}

The body of Turquoise-glazed Ware can be yellow, buff or light pink, and is fine-grained, compact and hard. The glaze is applied directly to the body, and ranges in colour between turquoise and green. Both open and closed vessel forms are documented (Fig. 6: 5). Turquoise-glazed Ware is characterized by strongly localized features, as with unglazed pottery. At present, the literature offers very little evidence pertaining to the production of this ware in Syria. This is especially true for the Jazira, where few excavations and surveys have been published. In the Euphrates Valley, it is often considered to be the most common variety of glazed pottery dating from 12 th century AD.

\section{References}

Tell Aswad: Watson 1999, 83, pl. 97: f-h. Qa'lat Ja'bar: Tonghini 1998, 55-56.

'Ana: Northedge et al. 1988, fig. 46: 3-5.

Tell Hrim: Berthier and Geyer 1988, 97.

Malabiya: Lebeau et al. 1985, 1-5.

Tell Barri: Scerrato and Ventrone-Vassallo 1982, pl. II: 12-13, 15, 17. Terqa: Mahmud 1978, 95-114.

Qasr al-Hair al-Sharqi: Grabar et al. 1978, 114.

Balis/Maskana: Golvin and Raymond 1974, 107-11.

\section{Monochrome-glazed Slip-ware}

The body is light orange, pinkish red, or more rarely light buff, and is hard and compact. This group is known for its morphological variety. The most common shape is a hemispherical bowl (Fig. 6.6), occasionally carinated, with a slightly upturned rim, which is often grooved on the exterior. A few closed forms are also represented in this group, together with oil lamps. Monochrome-glazed Slip-ware is one of the most common varieties of glazed pottery found in Syria. After the 12th century AD it appears to have replaced Turquoise-glazed Ware in the Western Mesopotamia, where it functioned as common glazed pottery. Chronologically, this group probably dates to the Mamluk period (late 13th-14th centuries $\mathrm{AD})$. 

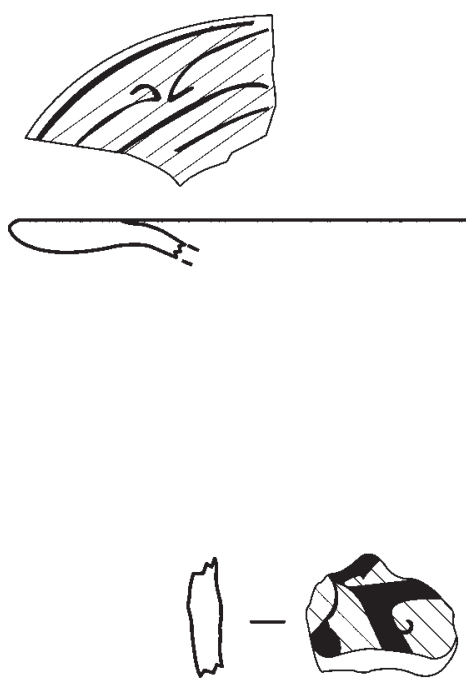

2

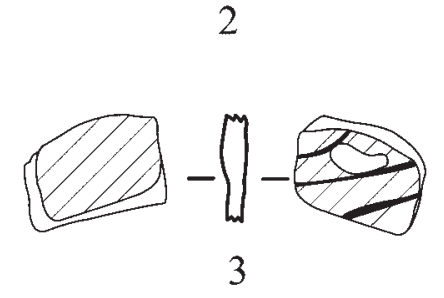

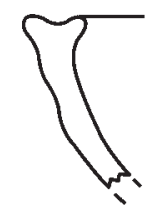

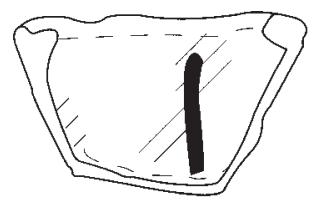

4

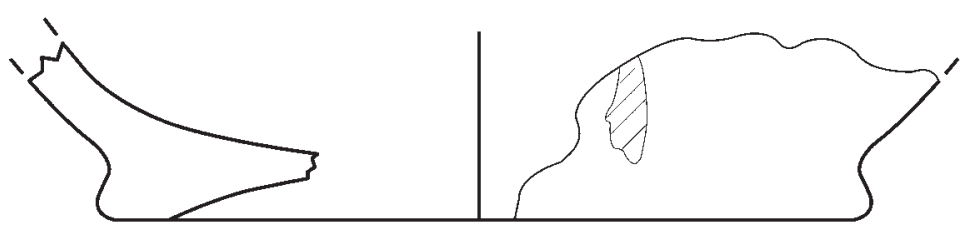

5
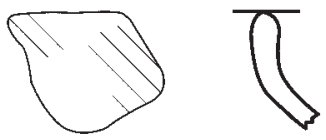

6

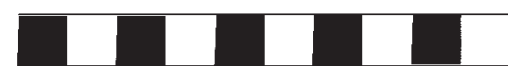

Figure 71 Shair 43: Sgraffiato Ware. Incised decorations under transparent green glaze; 2 Shair 35: Sgraffiato Ware. Incised decorations under transparent yellow glaze; 3 Shair 60: Sgraffiato Ware. Incised decorations under transparent green glaze; 4 Shair 47: Sgraffiato Ware. Thick incised decorations under transparent green glaze; 5 Shair 58: Sgraffiato Ware. Incised decorations under transparent green glaze, not well conserved on the inner surface. Drop of green glaze on the outer surface; 6 Nasr RM 22: Sgraffiato Ware. Incised decorations under transparent yellow glaze

\section{References}

Qa'lat Ja'bar: Tonghini 1998, 63-64.

Jerusalem: Tushingham 1985, fig. 34: 24, 27, 29, 30 .

Cesarea: Pringle 1985, 177-79.

Busra: Berthier 1985, 8, 14, pl. 6: 83.

Tripoli: Salamé-Sarkis 1980, group A.III, 186-91.

Tell 'Arqa: Thalmann 1978, types C, D, 24

Damascus: Toueir 1973, 211-12, pl. I-B.

\section{Sgraffiato Ware}

The body is light orange, pinkish red, or more rarely, light buff and is hard and compact. Occasionally it contains a very low percentage of extremely fine sand and, rarely, larger quartz grains.
Variations in the colour of the body depend on the percentage of lime, and also on the firing. The ware is normally associated with open forms, in most cases bowls. The most common form appears to have been a shallow bowl with a flat, everted rim and curving sides, with a diameter varying between 22 and $30 \mathrm{~cm}$. The interior of the bowls and the upper part of the exterior are covered with a slip, white, creamy or slightly pinkish in colour. The decoration is deeply scratched through the slip. Incisions may be of two types, less than one $\mathrm{mm}$ in width, between 2 and $5 \mathrm{~mm}$ in width, with 


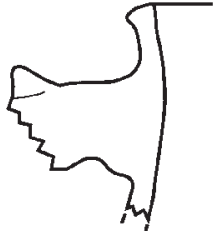

1

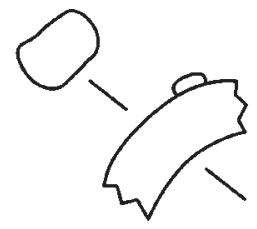

2

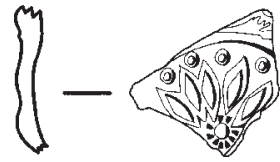

3

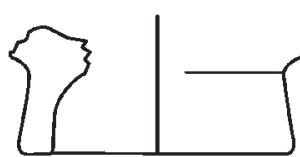

4

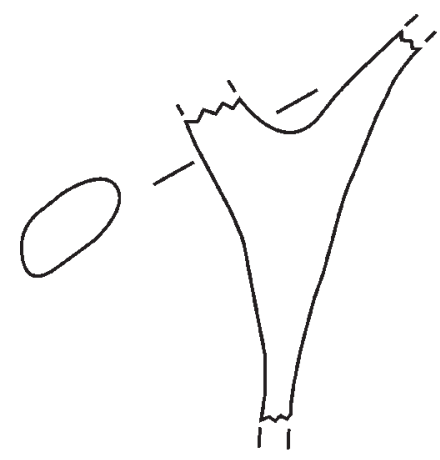

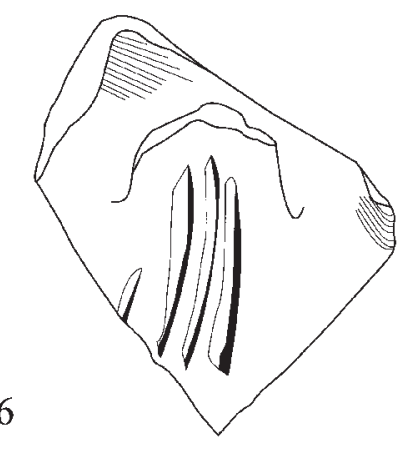

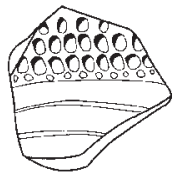

5

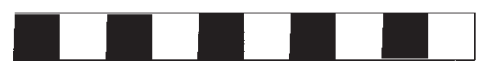

Figure 81 Awena 23: Buff Ware. Jug with everted rim and handle with knob; 2 Shair 44: Buff Ware. Little handle with knob; 3 Shair SE 21: Buff Ware with stamped decoration; 4 Gir Sikha 174: Buff Ware; 5 Aremish 4: Pale Green Ware with rouletted decoration; 6 Gir Sikha 1: Pale Green Ware with incised decoration; 7 Gir Sikha 64: Wheelthrown Ware. Light brown body

coloured pigments applied over the incised decoration. The glaze covers the entire inner surface and part of the exterior. This is a transparent lead glaze and can be either polychrome or monochrome. Since the glaze is directly in contact with the body the incised pattern appears black after firing. On the basis of parallels drawn from the previous literature, two different groups have been identified. These groups differ from each other in the width of their decorative incisions, a distinction which may have chronological significance.

a. Sgraffiato Ware with incisions of less than one $\mathrm{mm}$ in width. Examples of this type have been found at a number of sites with Crusader occupation and which were generally abandoned in the second half of the 13th century AD. This dating is also confirmed by evidence from sites like Hama, 'Atlit and, especially, Tripoli (Fig. 7: $1-3)$.

References

'Atlit: Riavez 2001, 505-32.

Akko: Stern 1997, 51-58, figs 10-13.

Tripoli: Salamé-Sarkis 1980, 161-69.

Hama: Poulsen 1957, 115-283.

Antioch: Waagé 1948, 88-108.

a. Sgraffiato Ware with incisions between 2 and $5 \mathrm{~mm}$ in width. This type is attributed to a later date than the previous form. At Tripoli it is ascribed to the Mamluk period (first half of the 14th century AD), while in Western Mesopotamia and Northern Syria this Sgraffiato Ware may be considered post-Ayyubid (Fig. 7: 4-6).

\section{References}

Qa'lat Ja'bar: Tonghini 1998, 57-62.

Caesarea: Pringle 1985, 183-86, figs 6: 37-38, 7-10.

Tripoli: Salamé-Sarkis 1980, 171-76. 

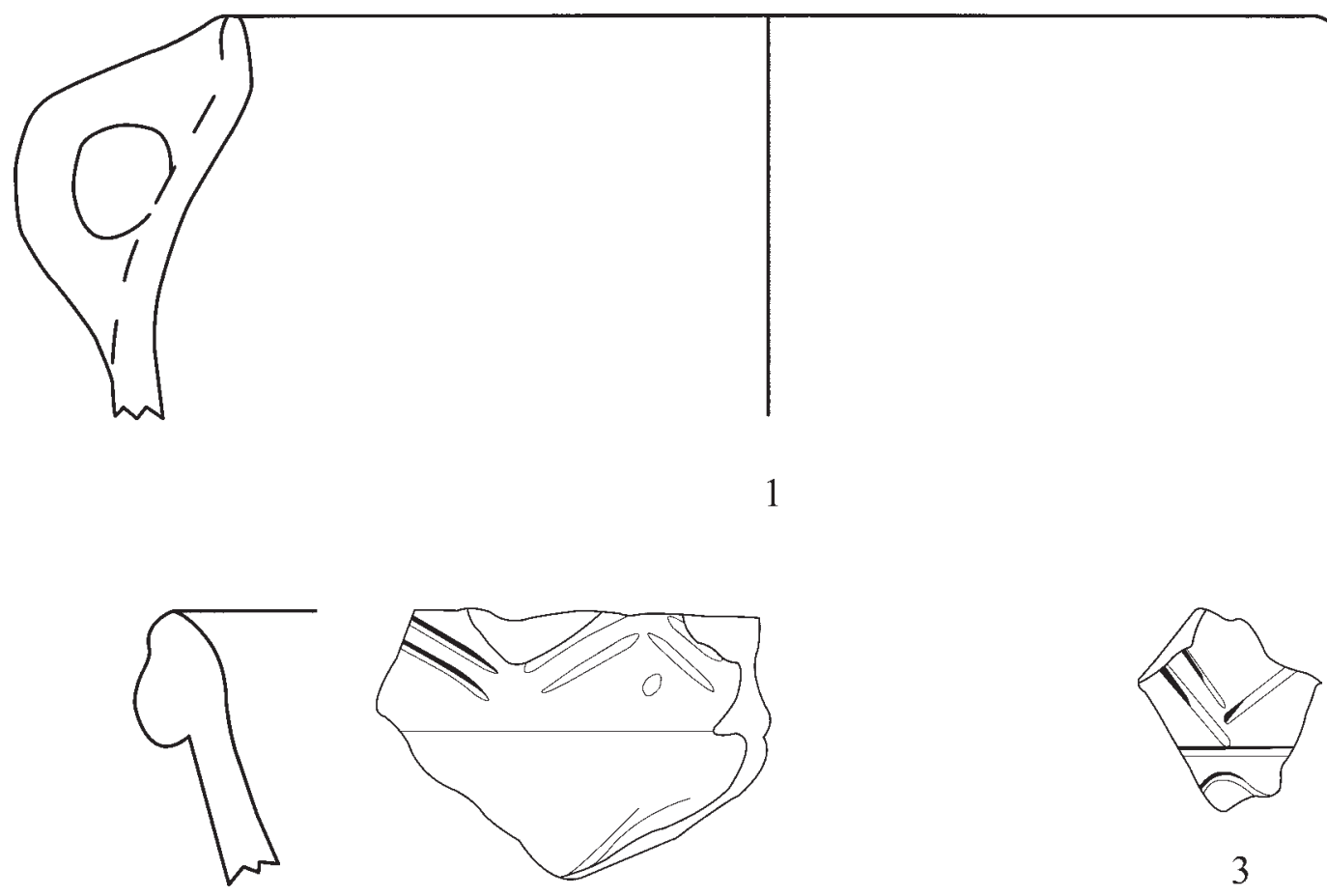

2
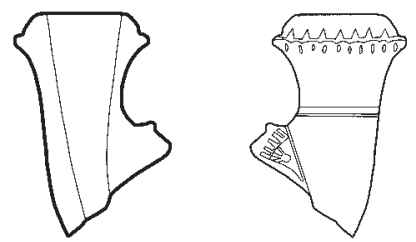

4

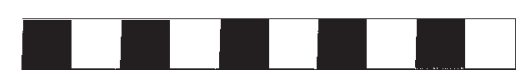

Figure 91 T. Leilan T 2-3 12: Cooking Ware; 2 Gir Sikha 121: Rustic Ware. Handmade ware with incised decoration; 3 Gir Sikha 70: Rustic Ware. Handmade ware with incised decoration; 4 Lazaqa 11: Ottoman pipe; 5 Sharmukh SS 5: Glass bangle

Polychrome Sgraffiato Ware appears to have been a fairly common variety of pottery after the Mongol invasions of $1259-60 \mathrm{AD}$.

\section{Unglazed Pottery}

The unglazed ceramic assemblage represents around $75 \%$ of the assemblage from the 1995 survey, but has only been studied in a preliminary way, because of the paucity of comparanda in the archaeological literature. In many areas of the Islamic world, unglazed pottery remains poorly understood, and as little has been published regarding this material in the Jazira, we lack a well-dated reference corpus. This is especially frustrating, since unglazed pottery shows strong local connotations, which suggests that the search for parallels should be restricted to a limited area. It has, however, been divided according to wares and tentatively grouped by shapes.

\section{Buff Ware}

The body shows a large variety of buff colours, with a yellowish, orange or pink hue. The ware is hard, compact and fine-textured with a surface that is often lighter than the core. This group is often decorated with a variety of techniques: incision, impression and application (Fig. 8: 1-4). Buff Ware was employed extensively for storage and transport, but was also used for food preparation. Buff Ware is found in a variety of shapes, some of which are closely related to those employed for glazed pottery. It is also related to 
Pilgrim Flasks. While handles are not considered a good chronological indicator; double handles and turban handles may be exceptions (Adams 1970, 98). These seem to have been produced in Syria since the early Abbasid period (8th-9th centuries AD) but were still in use during the middle Abbasid period (10th11 th centuries $\mathrm{AD}$ ).

\section{References}

Qa'lat Ja'bar: Tonghini 1998, 63-65, figs $104-44$, pls 53-72. Balikh: Bartl 1996, 335, fig. 4: 1-2.

Tell Shahin: Tonghini 1995, fig. $8 \mathrm{~g}$.

Tell Abu Sarifa: Adams 1970, 98

The absence of well-documented and dated assemblages in the archaeological literature renders it impossible to provide reliable chronological correlations. However, this unglazed group is very common, and appears to emerge at the end of 8th century AD, and continues in production until the 13th century AD.

\section{References}

Deir ez-Zor: Berthier et al. 2001.

Qa'lat Ja'bar: Tonghini 1998, 63-65, figs 104 44, pls 53-72.

North Jazira, Iraq: Wilkinson and Tucker 1995, 106, type 83 (9th-10th centuries) and type 122 (12th-13th centuries).

Samarra: Northedge and Falkner 1987, fig. 12: 55.

Qasr al-Hair al-Sharqi: Grabar et al. 1978, A3, A5, A7.

\section{Pale Green Ware}

This ware is made from a pale greenish fabric and is quite coarse, and shows both mineral and vegetal inclusions. A characteristic feature is a rouletted decoration, consisting of a broad band of deep rouletting around bowl rims or jar necks, but incised decoration is also frequent (Fig. 8: 5-6). Pale Green Ware was extensively employed for storage and transport vessels. Surface associations indicate that this is a later Islamic ware, probably post-13th century $\mathrm{AD}$, and it may be a potential indicator for post-Mongol occupation.

\section{References}

North Jazira, Iraq: Wilkinson and Tucker 1995, 107, type 96. Tell al-Hawa: Ball et al. 1989, fig. 27: 23.

\section{Common Wheel-thrown Ware}

The body is generally light buff with yellowish, pinkish and reddish tones. The clay seems to have been finely sifted and it is generally well smoothed. The body is hard, compact and very fine in texture. Common Wheel-thrown Ware is often associated with vessels with relief decoration, but also with jugs, ewers and small jars (Fig. 8: 7). The decoration often appears on the vessel shoulder, but vessel walls may also be decorated. The literature suggests that earlier jug forms with a high rim are generally related to the Abbasid period, but types of jugs and ewers continued in production until the 13th century AD.

\section{References}

Qa'lat Ja'bar: Tonghini 1998, Ware 1, 63-65, figs $104-44$. Balikh: Bartl 1996, 335, fig. 4: 1-2.

Tell 'Arqa: Hamikian and Salamé-Sarkis 1988, fig. 12: 1, pl. VII: 1. 'Ana: Northedge et al. 1988, 21, 102.

\section{Cooking Ware}

The body is red or dark brown, with large inclusions. External soot deposits indicate use as a cooking vessel. Most of the sherds from the survey belong to a type of closed, neckless cooking pot with a globular profile (Fig. 9:1) and folded rim. The body can be decorated with grooves or incisions. This is a local production and difficult to date. On the basis of the archaeological evidence provided by other excavations in the Khabur Valley, one can suggest a date between the 12th and the 14th centuries AD.

\section{References}

Tell Tunaynir: Fuller and Fuller 2000.

Khabur: Lyonnet 1992, 109-10.

Tell Barri: Scerrato and Ventrone-Vassallo 1982

\section{Rustic Ware}

This is a handmade product, the fabric of which shows a wide range of colours, from pale yellowbrown to light red and grey, depending upon firing. There are frequent inclusions of mineral and vegetal tempers. The majority of the assemblage consists of closed forms, which seem to have served a utilitarian function (Fig. 9: 2-3). This type of pottery has been identified at various sites in the Khabur Valley and may have been in production for a period extending from the 12th to the 14th centuries AD.

\section{References}

Khabur: Lyonnet 1992, 109-10, fig. 9, pl. VII: g-i.

Tell Barri: Scerrato and Ventrone-Vassallo 1982, 78.

\section{Other Objects}

Pipes

Material in this group has a dark grey body, composed of hard-fired, finely-sifted clay. All pipe fragments are decorated. This can take rouletted, stamped, impressed or incised forms; often all these techniques are combined on the same pipe (Fig. 9: 4). Smokers' pipes have been attributed to the Ottoman period in general. However, tobacco was only introduced in the Ottoman Empire at the beginning of the 17th century, and smoking was not popular until quite late in the century. 


\section{References}

Qa'lat Ja'bar: Tonghini 1998, 68; fig. 150: a, b, d.

Ottoman Clay Pipes: Simpson 1990a, 6-10.

Jerusalem: Simpson 1990b, 10.

Mytilene: Humphrey 1990, 2-9.

\section{Glass}

Glass was not recovered in significant quantities, and so little can be said about glass production in the region. Glass fragments were composed of very thin, blown glass; in most cases transparent, although glass also occurs in light green, brown, dark yellow or cobalt blue colours. The glass bangles from the 1995 season were of circular cross-section and were twisted (Fig. 9: 5). The archaeological literature attributes this type of bangle to the Mamluk period or later.

\section{References}

Qa'lat Ja'bar: Tonghini 1998, 34.

Steppe als Kulturlanschaft: Bernbeck 1993, ab. 153: f, g.

\section{Conclusions}

On the basis of the evidence discussed above, three main historical phases, characterized by different settlement patterns, can be identified in this part of the Khabur Valley. So far, no material evidence has been found indicating occupation in the first two centuries of the Islamic period (7th and 8th centuries $\mathrm{AD}$ ), but this is partly due to our limited understanding of the archaeological indicators for the Early Islamic Period. However, this phase is well recorded at excavated sites in other parts of the Jazira, so it is possible that the Khabur Valley was still a border land, and only occasionally occupied at this time.

1) 9th-11th centuries $A D$ (Fig. 3). This is the period of the Abbasid road. Adhrama, which was an important station of this route, was probably located within the survey area which was, therefore, not completely isolated from international traffic. However, during this period the caliphate was in a state of economic and political crisis, and tribal groups began to threaten the security of the trade route. On the basis of the material evidence, 19 sites of the Leilan survey have been attributed to this period. Three of them can be considered as major centres in a relative sense: Gir Sikha (site 116), Shair (site 74) and Sharmukh (site 59). One of these sites may be tentatively identified with Adhrama. Although Islamic settlement developed mainly in the north-west of the survey area, some sites to the south-east were also settled.

2) 12th-14th centuries $A D$ (Fig. 4). Two dynasties controlled the region during this phase: the Ayyubid dynasty, during the 12th-13th centuries $\mathrm{AD}$ and the
Mamluks, from the late 13th to the second half of the 14 th century AD. This was a period of security and economic development for the area, as reflected in an observed increase in the number of sites occupied. A total of 39 sites are associated with this period. Four of them can be considered relatively major centres: Gir Sikha (site 116), Shair (site 74), Sharmukh (site 59) and Tell Haid (site 90). All of them are located to the northwest of Tell Leilan. Generally, settlement growth was most pronounced in the northern part of the area. This picture of relative prosperity is confirmed by the excavation data from Tell Barri (Pecorella 1982) and Tell Tuneyinir (Fuller and Fuller 2000) in neighbouring regions. Even though medieval sources mention that the entire Jazira was destroyed by the Mongol invasion in $1260 \mathrm{AD}$ this is not supported by the survey data as currently understood.

3) 15th-19th centuries $A D$ (Fig. 5). The number of occupied sites decreased significantly during this period, with only 5 sites still occupied. The material evidence shows that the main centres were still Gir Sikha (site 116) and Shair (site 74), but without a significant presence of Islamic pottery. Particulalry characteristic of this period is the production of unglazed pottery, which, together with a few fragments of clay pipes, might point to a nomadic occupation. After the Mamluk period, the region suffered the continuing threat from tribal groups, as reported by various European travellers to the region, including Lady Anne Blunt (1968, 182) and Sir Henry Layard (1853).

This preliminary description of the Islamic occupation in the Tell Leilan region has been achieved by combining archaeological and documentary sources. The written sources play only a limited role in the reconstruction of the historical and social context of this rural area as they make little mention of local centres and villages, and they make little contribution to the reconstruction of the dynamics of the rural settlement, or the impact of major historical events on this region. However, the archaeological record is able to provide better information on the nature and the intensity of the human settlement activity during the Islamic period, and thanks to the work of the survey it has been possible to identify additional sites, some of which appear to have been large villages, and to therefore understand the temporal trends in the evolution of human activity in the region in the light of political and social developments.

\section{Bibliography}

\section{Medieval Sources}

Al-Hamdani, Muhammad al-Hasan b. Ahmad (1968) Sifat Jazirat alArab. Leida. 
Al-Muqaddasi, Abu 'Abd Allah Muhmmad b. Ahad (1967) Kitab ahsan al-taqasim fi ma'rifat al-'aqalim. Leida: Bibliotheca Geographorum Arabicorum.

Ibn Battuta (1950-57) Tuhfat al-nuzzari fi ghra'ib al-amsar, Dass wa muntakhbat bi-qaham Fu'ad Afram al-Bustani. Beirut: AlMatba'ah al-nathubikiyya.

Ibn Hawqal, Abu al-Qasim Muhammad (1964) Kitab surat al-'ard. Leida: Bibliotheca Geographorum Arabicorum.

Ibn Khurradadbih (1967) Kitab al-masalik wa al-mamalik. Leida: Bibliotheca Geographorum Arabicorum.

Ibn Shaddad, 'Izz al-Din Muhammad b. 'Ali (1984) Description de la Syrie du Nord. Translation and commentary by Eddé-Terrasse. Institut Français de Damas.

Yaqut, al-Mamawi (1977) Mu'jam al-buldan. Beirut.

\section{Modern Works}

Adams, R. McC. (1970) Tell Abu Sarifa, A Sassanian-Islamic sequence from South Central Iraq. Ars Orientalis 8, 87-120.

Ball, W., Tucker, D. and Wilkinson, T.J. (1989) The Tell al-Hawa project: archaeological investigations in the North Jazira 1986-87. Iraq 51, 1-66.

Bartl, K. (1993-94) Remarks concerning the historical topography of the Balikh Valley, Northern Syria, during the Early Islamic Period. Berytus 41, 29-38.

- (1996) The Balikh Valley Survey: settlements of the Late Roman/ Early Byzantine and Islamic Period. Pp 333-48, in K. Bartl and S. Hauser (eds), Continuity and Change in Northern Mesopotamia from Hellenistic to the Early Islamic Period. Ausgrabungen 17. Berlin: Berliner Beiträge zum Vonderen Orient.

Ben-Tor, A., Portugali, Y. and Avissar, M. (1979) The second season of excavation at Tel Yoqne'am, 1978: Preliminary Report. Israel Exploration Journal 29/2, 65-83.

Bernbeck, R. (1993) Steppe als Kulturlanschaft. Ausgrabungen I. Berlin: Berliner Beiträge zum Vonderen Orient.

Berthier, S. (1985) Sondage dans le secteur des thermes sud à Busra (Syrie) 1985. Berytus 33, 5-45.

- and Geyer, B. (1988) Rapport Préliminaire sur une campagne de fouilles de sauvetage a Tell Hrīm (Syrie) - Hiver 1986. Syria 65, 63-98.

- Chaix, L., Studer, J., D'Hont, O. and Samuel, D. (2001) Le peuplement rural de la moyenne vallée de l'Euphrate à l'époque islamique (VIIe-XIXe siècle): Étude régional Deir ez-ZorlAbu Kamal (Syrie). Damas: Institut Français d'Études Arabes.

Besonen, M. and Cremaschi, M. Geomorphological field survey (Tell Leilan June 2002). Internet edition: http://leilan.yale.edu/works/ geo_report/index.html.

Blunt, A. Lady (1968) Bedouin Tribes of the Euphrates. London: Frank Cass \& Co. Ltd

Courty, M.-A. and Weiss, H. (1997) The scenario of environmental degradation in the Tell Leilan Region, NE Syria, during the late third millennium abrupt climate change. Pp. 107-47 in N. Dalfes, G. Kukla and H. Weiss (eds), Third Millennium BC Climate Change and Old World Collapse. Series I: Global Environmental Change.

Berlin: NATO ASI Series: Series I: Global Environment Change.

De Aloe, I. (2002-03) Un'analisi delle ceramiche dalla ricognizione di Tell Leilan (Siria nord-orientale) nel contesto dell'Alta Mesopotamia tra Ellenismo ed Età Sasanide. Unpublished MA thesis, Dipartimento di Scienze dell'Antichità e del Vicino Oriente, Università Ca' Foscari di Venezia.

Ettinghausen, R. and Grabar, O. (1991) The Art and Architecture of Islam 650-1250. London: Penguin Books, 111.

Fiey, J. M. (1964) The Iraqi section of the Abbasid Road MosulNisibin. Iraq 26, 107-17.

Fuller, M. and Fuller N. (2000) The 2000 Season at Tell Tuneinir, Syria. Annual meeting of the American School of Oriental Research Nashville TN, 18 November 2000

Golvin, L. and Raymond, A. (1974) Meskeneh/Balis, Exposition des découverts de la campagne internationale de sauvegarde des antiquités de l'Euphrate. Alep: Musée National d'Alep, 107-11.

Grabar, O., Holod, R., Knustad, J. and Trousdale, W. (1978) City in the Desert: Qasr al-Hair East. Harvard University Press.

Haase, C.-P. (1991) Madinat al-Far: first archaeological soundings at the site and the history of an Umayyad domain in Abbasid Times. Pp 206-25 in M.A. Al-Bakhit and R. Schick (eds), Bilad al-Sham During the Abbasid Period, Proceedings of the Fifth International Conference on the History of Bilad al-Sham.
- (1996) The regional Late Antique tradition of an Early Islamic foundation. Pp. 165-71 in K. Bartl and S. Hauser (eds), Continuity and Change in Northern Mesopotamia from Hellenistic to the Early Islamic Period. Ausgrabungen 17. Berlin: Berliner Beiträge zum Vonderen Orient.

- (2001) Une ville des débuts de l'Islam d'après les fouilles effectuées à Madinat al-Far (Syrie du Nord). Les premières fondations urbaines umayyades. Archéologique Islamique 11, 7-20.

Hamikian, S. and Salamé-Sarkis, H. (1988) Céramiques médiévales trouvées dans une citerne à Tell 'Arqa. Syria 65, 1-52.

Humphrey, J. W. (1990) The Turkish clay smoking pipes of Mytilene. Society for Clay Pipe Research, Newsletter 26, April, 2-9.

Lane, A. (1938) Medieval finds at Al Mina in North Syria. Archaeologia 87, 19-78.

Layard, A. H. (1853) Discoveries among the Ruins of Niniveh and Babylon. New York: Putnam.

Lebeau, M., Gubel, E. and Monchambert, J.-Y. (1985) Rapport préliminaire sur la première campagne de fouilles à Tell Melebiya (moyen-Khabour-primtemps 1984). Akkadika 45, 1-15.

Lyonnet, B. (1992) Reconnaissance dans le Haut Habur: étude de la céramique. Pp. 103-32 in J.-M. Durand (ed.), Recherches en Haute Mésopotamie. Tell Mohammed Diyab. Campagnes de 1990 et 1991. Mémoires de N.A.B.U. 2: Paris.

Mahmud, A. (1978) Terqa Preliminary Reports, No. 5: Die Industrie der Islamischen Keramik aus der Zweiten Season. SyroMesopotamian Studies 2/5, August, 95-114.

Mason, R. B. (1995) Defining Syrian stonepaste ceramics: petrographic analysis of pottery from Ma'arrat al-Nu'man. Pp. 1-18 in J. Allan (ed.), Islamic Art in the Ashmolean Museum, Part Two. Oxford Studies in Islamic Art X.

Mc Phillips, S.A. (2004) Pottery of the ninth to thirteenth centuries from the Citadel of Damascus. Unpublished PhD thesis, University of Sidney.

Meijer, D.J.W. (1986) A Survey in Northeastern Syria. PIHANS 58. Leiden.

Meinecke, M. (1991) Raqqa on the Euphrates: recent excavations at the residence of Harun al-Rashid. Pp. 17-32 in S. Kerner (ed.), The Near East in Antiquity 2.

- (1995) Al-Rakka. Enciclopedie Islamique ${ }^{2}$ 8, 424-28.

Meinecke, M. and Heusch, J.-C. (1985) Grabungen im 'abbasidischen Palastreal von ar-Raqqa/ar-Rafiqa. Damaszener Mitteilungen 2, 85-105.

Northedge, A. (1985) Planning Samarra: A report for 1983-4. Iraq 47, 109-18.

- (1996) Friedich Sarre's Die Keramik von Samarra in perspective. Pp. 229-58 in K. Bartl and S. Hauser (eds), Continuity and Change in Northern Mesopotamia from Hellenistic to the Early Islamic Period. Ausgrabungen 17. Berlin: Berliner Beiträge zum Vonderen Orient.

- and Falkner, R. (1987) The 1986 survey season at Samarra. Iraq 49, 143-73.

- Bamber, A. and Roaf, M. (1988) Excavation at 'Ana. Warminster: British School of Archaeology in Iraq.

Pecorella, P.E. (1982) Tell Barri/Kahat 2. Documenta Asiana 5.

Pringle, D. (1984) Thirteenth-century pottery from the monastery of St. Mary of Carmel. Levant 16, 91-111.

- (1985) Medieval pottery from Cesarea: The Crusader period. Levant 17, 171-202.

Porter V. and Watson, O. (1987) Tell Minis Wares. Pp. 175-48 in J. Allan and C. Roberts (eds), Syria and Iran: Three Studies in Medieval Ceramics. Oxford: Oxford Studies in Islamic Art IV

Poulsen, V. (1957), Les poteries médiévales. Hama. Fouilles et recherches de la Fondation Carlsberg 1931-1938. IV/2, Copenhagen, 115-283.

Redford, S. (1995) Medieval ceramics from Samsat, Turkey. Archéologie Islamique 5.

Riavez, P. (2001) 'Atlit — ceramica Port St. Symeon 1217-1291, graffite crociate del Mediterraneo orientale. Archeologia Medievale 28, 505-32.

Rice, D.S. (1952) Studies in medieval Harran: Studies on its topography and monuments, I. Anatolian Studies 2, 36-84.

Riis, P.J. (1957) Les données historiques et stratigraphiques. Hama. Fouilles et recherches de la Fondation Carlsberg 1931-1938. IV/2, Copenhagen, 1-29.

Ristvet, L. (2002) In the land of Apum: settlement pattern around Tell Leilan (2400-1700 BC). Proceedings of the 3rd ICAANE Conference, Paris 2002. 
- (2005) Settlement, Economy, and Society in the Tell Leilan Region, Syria, 3000-1000 BC. PhD Dissertation, University of Cambridge, 22 July 2005.

- and Weiss, H. (2005) The Häbür region in the late third and early second millennium BC. In W. Orthmann (ed.), The History and Archaeology of Syria. Vol. 1. Saarbrucken: Saarbrucken Verlag.

Rogers, J. M. (1984) Medieval pottery at Apamea in the 1976 and 1977 seasons. Pp. 261-87 in J. Balty (ed.), Apamée de Syrie. Bilan des recherches archéologique 1973-1979. Brussels.

Salamé-Sarkis, H. (1980) Contribution a l'histoire de Tripoli et de sa région à l'époque des Croisades: Problèmes d'histoire, d'architecture et de céramique. Paris: Bibliothèque Archéologique et Historique 106.

Saliby, N. (1983) At-tanqib fi Madinat al-Far hisn Maslama. Annales archéologiques de la Syrie 33, 69-88.

Sarre, F. (1925) Die Keramik von Samarra, Die Ausgrabungen von Samarra. Forschungen zur islamischen Kunst 2.

Scerrato, U. and Ventrone-Vassallo, G. (1982) La ceramica islamica. Tell Barri/Kahat 1. Relazione preliminare sulla campagna 1980 1981. Roma, 77-88.

Simpson, St J. (1990a) A brief introduction to Ottoman clay pipes. Society For Clay Pipe Research, Newsletter 27, 6-10.

- (1990b) Ottoman clay pipes from Jerusalem and the Levant: A critical review of the published evidence. Society For Clay Pipe Research, Newsletter 28, 7-16.

Stein, G.J. and Wattenmaker, P. (1990) The 1987 Tell Leilan regional survey: Preliminary report. Pp. 5-18 in N. Miller (ed.), Economy and Settlement in the Near East. Philadelphia: MASCA Research Papers in Science and Archaeology.

- (2003) Settlement trends and the emergence of social complexity in the Leilan region of the Khabur Plains (Syria) from the fourth to the third millenium BC. Pp. 361-86 in E. Rova and H. Weiss (eds), The Origins of North Mesopotamian Civilization: Ninevite 5 Chronology, Economy, Society. Brussels: Brepols.
Stern, E.J. (1997) The pottery of the Crusader and Ottoman Periods. 'Atiqot 31, 35-70.

Thalmann, J.P. (1978) Tell 'Arqa (Liban Nord). Campagnes I-III (1972-1974). Syria 55, 1-144.

Tonghini, C. (1995) A new Islamic pottery sequence in Syria: Tell Shahin. Levant 27, 197-207.

- (1998) Qal'at Ja'bar Pottery: A Study of a Syrian Fortified Site of the Late 11th-14th Century. Oxford: Oxford University Press.

Toueir, K. (1973) Céramiques mameloukes à Damas. Bulletin d'Études Orientales 26, 209-17.

Tushingham, A.D. (1985) Excavation in Jerusalem 1961-1967 I. Toronto: Royal Ontario Museum.

Vezzoli V. (2003-04) L'insediamento di epoca islamica nell'area di Tell Leilan (Jazira settentrionale): studio del materiale ceramico. Unpublished MA thesis, Dipartimento di Studi Euroasiatici, Università Ca' Foscari di Venezia.

Waagé, F.O. (1948) Ceramics and Islamic coins. Antioch-on-theOrontes. Princeton, 88-108.

Watson, O. (1999) Report on the glazed ceramics. Pp. 81-87 in P.A. Miglus (ed.), Die Frühislamische Keramik von Tall Aswad. Mainz am Rein: Philipp von Zabern.

Weiss, H. (1986) The origins of Tell Leilan and the conquest of space in 3rd millennium Mesopotamia. Pp. 71-108 in H. Weiss (ed.), The Origins of Cities in Dry-Farming Syria and Mesopotamia in the Third Millenium BC. Guilford.

- (2003) Ninevite 5 periods and processes. In E. Rova and H. Weiss (eds), The Origins of North Mesopotamian civilization: Ninevite 5 Chronology, Economy, Society. Brussels: Brepols.

Weiss, H. et al. (2002) Revising the contours of history at Tell Leilan. Annales Archeologiques Arabes Syriennes, Cinquantenaire.

Wilkinson, T.J. and Tucker, D. (1995) Settlement-Development in the North Jazira, Iraq. A Study of the Archaeological Landscape (Iraq Archaeological Reports 3). Warminster: Wiltshire. 